Thorax, 1981, 36, 299-302

\title{
Time and place for sputum cytology in the diagnosis of lung cancer
}

\section{F HARTVEIT}

From the Norwegian Cancer Society and The Gade Institute, Department of Pathology, The University, Bergen, Norway

ABSTRACT Despite ready access to medical care $91 \%$ of patients dying of lung cancer derived from a population of just under 400000 are shown to have presented too late for other than palliative treatment. As the incidence and death rates from lung cancer in the district were very similar, few survivors can be expected. Morphological confirmation of the diagnosis was available in $96 \%$ of cases. The first positive morphological diagnosis was obtained from sputum cytology taken on admission in $69 \%$ of all cases and in $77 \%$ of those in whom there had been delay in diagnosis. More extensive use of this investigation on an outpatient basis is urged.

The incidence of lung cancer is low in Norway but, as in other countries, it is rising and taking up an increasing amount of our time and resources. It was the most frequent cancer diagnosis at necropsy in this department in 1976 and 1977 . The majority of the patients had been admitted too late for other than palliative treatment. ${ }^{1}$

The aim of this study was to see if the course of the disease in the patients coming to necropsy was representative of that in patients with lung cancer in the district as a whole, to define the time at which a morphological diagnosis was first obtained, and identify factors responsible for late diagnosis.

\section{Methods}

Records from the Norwegian Cancer Registry showed that 183 deaths had been recorded in 1976 and 1977 in the county of Hordaland in patients said to have had lung cancer. This department is responsible for the necropsy, biopsy, and cytology services of the county. We were thus able to trace all but eight of these cases from our departmental files. Details of all surgical and cytological specimens were collected, including the date of investigation and the date of tumour diagnosis (histological or cytological).

Clinical information recorded included the sex and age of the patient at death, and the place of residence, in or outside the main town, Bergen. In 95 of the cases coming to necropsy $(79 \%)$ the presenting

Address for reprint requests: Professor F Hartveit, Department of Pathology, 5016 Haukeland Hospital, Bergen, Norway. symptom and the duration of the disease were traced from the clinical records. The duration of primary care before admission was recorded, and the smoking history checked.

\section{Results}

The 183 reported cases consisted of 153 men and 27 women (mean age at death 71 and 69 respectively).

Table 1 shows that the clinical diagnosis had been based on morphological confirmation of the primary tumour in 107 and of metastatic tumour in 32. The diagnosis was based on clinical evidence alone in only eight cases $(4 \%)$. Necropsy was carried out in 120 $(65 \%)$. There were 10 patients dying of lung cancer in whom the diagnosis had not been made clinically. Further, in 16 cases in whom the primary was confirmed at necropsy, the patient was shown to have died of an unrelated disease.

In those with necropsy certification the mean age $( \pm \mathrm{SD})$ at death was $68 \pm 10$ years and of those with clinical certification, $66 \pm 12$ years. Eighty-one per cent of the cases coming to necropsy were Bergen residents, compared with $44 \%$ of those with clinical certification.

In the 107 cases in which the primary was confirmed morphologically during life (table 2) the diagnosis was obtained most often (in $75 \%$ of cases) by means of exfoliative (sputum) cytology. The first positive was usually obtained by this method $(69 \%)$, histology being used less often and aspiration cytology on occasion. The level of investigation was similar in those with necropsy and those with clinical certifi- 
Table 1 Deaths recorded as due to lung cancer in Hordaland, 1976 and 1977.

\begin{tabular}{lccc}
\hline Clinical diagnosis based on & $\begin{array}{c}\text { Nunber } \\
\text { of cases }\end{array}$ & $\begin{array}{l}\text { Eeath certification } \\
\text { based on }\end{array}$ \\
\cline { 3 - 4 } & & Necropsy & $\begin{array}{c}\text { Clinical } \\
\text { findings }\end{array}$ \\
\hline $\begin{array}{l}\text { Morphological confirmation of } \\
\text { primary }\end{array}$ & 107 & 84 & 55 \\
$\begin{array}{l}\text { Morphological confirmation of } \\
\text { metastatic tumour }\end{array}$ & 32 & & \\
$\begin{array}{l}\text { Clinical diagnosis alone } \\
\text { Not diagnosed clinically (false } \\
\text { negative) }\end{array}$ & 10 & 10 & - \\
$\begin{array}{l}\text { Diagnosed clinically (false } \\
\text { positive at necropsy) }\end{array}$ & 3 & 3 & \\
Total & 183 & 120 & 63 \\
\hline
\end{tabular}

Table 2 Morphological investigations in 107 patients with lung cancer in which the diagnosis was confirmed morphologically during life, comparing the findings in those with necropsy certification of the cause of death with those with clinical certification

\begin{tabular}{|c|c|c|c|c|c|}
\hline \multirow{2}{*}{$\begin{array}{l}\text { Type of } \\
\text { certifica- } \\
\text { tion }\end{array}$} & \multirow{2}{*}{$\begin{array}{l}\text { Confirma- } \\
\text { tion of }\end{array}$} & \multicolumn{3}{|c|}{ Type of investigation } & \multirow{2}{*}{$\begin{array}{l}\text { Number of } \\
\text { cases }\end{array}$} \\
\hline & & Histology & $\begin{array}{l}\text { Exfoliative } \\
\text { cytology }\end{array}$ & $\begin{array}{l}\text { Aspiration } \\
\text { cytology }\end{array}$ & \\
\hline Necropsy & $\begin{array}{l}\text { Primary } \\
\text { Metastasis } \\
\text { First } \\
\text { positive }\end{array}$ & $\begin{array}{r}25 \\
9 \\
28\end{array}$ & $\begin{array}{r}51 \\
2 \\
44\end{array}$ & $\begin{array}{r}11 \\
5 \\
14\end{array}$ & 65 \\
\hline Clinical & $\begin{array}{l}\text { Primary } \\
\text { Metastasis } \\
\text { First } \\
\text { positive }\end{array}$ & $\begin{array}{r}17 \\
8 \\
22\end{array}$ & $\begin{array}{r}30 \\
2 \\
30\end{array}$ & $\begin{array}{l}3 \\
0 \\
3\end{array}$ & 42 \\
\hline
\end{tabular}

cation. Further, only 17 cases were submitted for operation, that is $16 \%$ of the cases with morphological confirmation of the diagnosis before death.

Table 3 shows the survival time from the onset of symptoms in $95(79 \%)$ of the patients with necropsy confirmation. This was shortest in those presenting with dyspnoea, longest in those found on mass miniature radiography: $19 \%$ had been asymptomatic on admission, $47 \%$ presented with thoracic symptoms, and $11 \%$ with symptoms related to distant metastases. The symptoms did not appear to be age-related.

Relevant symptoms had been present for less than four w'c ks before consulting a doctor in 50, more than six months in seven. The duration of primary care was under one week in 39 , more than four in 22 . The interval between referral and admission to hospital was under one week in 53, and over three in seven. Only four of these cases were known to be nonsmokers; there was no smoking history in nine others. The remainder had smoked regularly for many decades. Thirty-two had had severe chronic bronchitis.
Table 3 Presenting symptoms in the patients with lung cancer related to the mean survival time from the onset of symptoms and to the mean age at death

\begin{tabular}{|c|c|c|c|c|}
\hline $\begin{array}{l}\text { Presenting } \\
\text { symptom }\end{array}$ & $\begin{array}{l}\text { Mean } \\
\text { survival } \\
\text { time }(\mathrm{mo})\end{array}$ & $\begin{array}{l}\text { Mean } \\
\text { age at } \\
\text { death }(v r)\end{array}$ & $\begin{array}{l}\text { Number } \\
\text { of cases }\end{array}$ & $\%$ \\
\hline $\begin{array}{l}\text { Dyspnoea } \\
\text { Dysphagia } \\
\text { Pneumonia }\end{array}$ & $3 \cdot 5^{*}$ & $71 \cdot 4$ & 12 & \\
\hline $\begin{array}{l}\text { Cough } \\
\text { Chest pain } \\
\text { Haemoptysis }\end{array}$ & $8 \cdot 3 * \dagger$ & $68 \cdot 7$ & 33 & 47 \\
\hline $\begin{array}{l}\text { Bone metastases } \\
\text { CNS metastases }\end{array}$ & $5 \cdot 3$ & $63 \cdot 8$ & 10 & 11 \\
\hline $\begin{array}{l}\text { Asymptomatic } \\
\text { incidental }\end{array}$ & $6 \cdot 0$ & $66 \cdot 0$ & 8 & 19 \\
\hline $\begin{array}{l}\text { mass miniature } \\
\text { radiography }\end{array}$ & $13 \cdot 9 \dagger$ & $67 \cdot 0$ & 10 & \\
\hline Not stated & - & $69 \cdot 0$ & 15 & 16 \\
\hline Other & $11 \cdot 3$ & $71 \cdot 0$ & 7 & 7 \\
\hline All & $7 \cdot 9$ & $68 \cdot 3$ & 95 & 100 \\
\hline
\end{tabular}

*difference statistically significant $(\mathrm{p}<0.01)$.

$\dot{\gamma d f f e r e n c e ~ s t a t i s t i c a l l y ~ s i g n i f i c a n t ~}(p<0.02)$

Sputum cytology had been taken on admission in 64 of these patients. The very first specimen was positive in 32, including 17 of the 22 in whom the duration of primary care was over four weeks.

\section{Discussion}

The 180 cases dying of lung cancer reported here are derived from a population of 389164 over a two-year period. Possible survivors are not included. The incidence in Hordaland as reported by the Norwegian Cancer Registry ${ }^{2}$ for the years $1972-76$ was 80 cases per year. The recorded death rate in the two years of the present study was 90 per year. This difference is probably caused by the inclusion of cases first diagnosed at necropsy in the latter figures. As the mean survival time recorded here was under one year, theoretical survivors will be few and will not affect the main issue.

The patients coming to necropsy are probably representative of those dying of the disease in the district as a whole. Their age at death was similar, as was the level of morphological investigation. The place of death, in or outside hospital, rather than the disease process, determined whether or not necropsy was carried out.

The problem of under-diagnosis of lung cancer ${ }^{3}$ is still relevant in this population. On the other hand approximately one in seven of those with known lung cancer of which they were thought to have died, were found at necropsy to have died of an unrelated cause, their lung cancer being confirmed, but considered a contributory cause of death. They can hardly be termed "survivors" as their disease was beyond treatment. They just happened to die before it killed 
them. On clinical death certification these cases would cancel out those underdiagnosed. ${ }^{4}$

The majority of the patients had been subjected to extensive investigation at the University Hospital at some time in their illness. The findings were such that only 17 of them could be submitted for operation, compared with, for example, over $50 \%$ in selected hospital series. ${ }^{5} 6$ This population had full access to an advanced health service at all levels. Even so our resources are being used to establish a diagnosis at a time when treatment is of little avail. It is unlikely that we are alone in this respect. In a study of a population of a similar size from the Grampian region in Scotland during the years 1968 and 1969, 433 patients were found to have colo-rectal cancer. ${ }^{\text {? }}$ Half the patients were incurable at the time of diagnosis. The authors pointed out that there are few studies on the occurrence of carcinoma of the large bowel and its course in the population of a defined area. The same is true of lung cancer, in which the overall picture gives even more cause for concern.

The majority of the patients were elderly. Contrary to previous suggestions, ${ }^{5}$ they usually reported their symptoms reasonably quickly. Delay here would seem difficult to remedy. The number of patients found by mass miniature radiography was low, as expected. ${ }^{8}$ These tumours are probably slow growing, showing up on screening before the symptoms appear. ${ }^{9}$ But the majority of the tumours presented and killed within a year. We cannot reasonably hope to use mass miniature radiography to find them. However, there was a group of cases in whom delay occurred as the physical signs were not obvious enough to justify an immediate request for admission. Sputum cytology gave the diagnosis on admission in 17 of 22 of them.

The diagnostic potential of sputum cytology is dependent on the experience of the laboratory concerned, ${ }^{10}$ but in capable hands it has been shown to be "the test most likely to give a positive result"11 in the diagnosis of primary lung cancer. All positive cytological results obtained in this series on patients that later came to necropsy were confirmed, and in many of the cases with clinical certification the cytological diagnosis had been confirmed histologically during life. The question of false negative results is closely associated with the quality of the material obtained. Even so, in this study sputum cytology was positive on the first specimen in the group of patients in which delay, because of diagnostic difficulties, had occurred before admission. While a negative result should not be accepted as proof of the absence of disease in the presence of clinical evidence to the contrary, a positive result may resolve a clinical suspicion before other supportive evidence is available. This can in many cases save the patient the trial of further diagnostic procedures.

The present findings stress the need for a sputum cytology service for outpatients, particularly smokers and others with chronic bronchitis, on clinical suspicion of lung cancer. Cytological examination of the sputum is little used on an outpatient basis. ${ }^{11}$ The Mayo lung project led the way in using sputum cytology on selected at-risk groups. ${ }^{12}$ Such screening has been shown to be effective in identifying both asymptomatic and radiologically occult cancer. Cytological examination of the sputum in outpatients in whom there is clinical suspicion of lung cancer has been reported from Czechoslovakia. ${ }^{13}$ Such investigation may enable us to shorten the time needed to establish a diagnosis in symptomatic patients and thus instigate palliative treatment earlier. Screening of asymptomatic at-risk groups in the population is a greater task, but one that may give the diagnosis in time for treatment to be effective.

My thanks are due to the Norwegian Cancer Registry for access to their records. Dr E Aspevik kindly gave access to the clinical records from his department and Professor $\mathrm{J}$ Chr Giertsen provided details of the medicolegal case from this department.

\section{References}

1 Hartveit F. Autopsy findings in cases with a clinically uncertain cancer diagnosis. J Pathol 1979; 129:111-9

2 Cancer Registry of Norway. Geographical Variations in Cancer Incidence in Norway, 1972-76. Oslo: The Norwegian Cancer Society, 1978: 46.

3 Heasman MA, Lipworth L. Studies on medical and population subjects. Accuracy of certification of cause of death. London: Her Majesty's Stationery Office, 1966: 51

4 Hartveit F. Clinical and post-mortem assessment of the cause of death. J Pathol 1977; 123:193-210.

5 Rostad H, Vale JR. Primær lungecancer. T Norske Lageforen 1978; 98:1670-3.

6 Stanford W, Spivey CG, Larsen GL, Alexander JA, Besich WH. Results of treatment of primary carcinoma of the lung. J Thorac Cardiovasc Surg 1976; 72:441-9.

7 Clarke DN, Jones PF, Needham CD. Outcome in colorectal carcinoma: seven-year study of a population. Br Med J 1980; 280:431-5.

8 Høst $H$. The value of periodic mass chest roentgenographic surveys in the detection of primary bronchial carcinoma in Norway. Cancer 1960; 13:1167-84.

9 Overholt RH, Neptune WB, Ashraf MM. Primary cancer of the lung. Ann Thorac Surg 1975; 20:511-9.

10 Oswald NC, Hinson KFW, Canti G, Miller AB. The diagnosis of primary lung cancer with special reference to sputum cytology. Thorax 1971; 26: 623-31.

11 Oswald NC, Hinson KFW, Canti G et al. Survey of 
the sputum cytology service in England and Wales. Thorax 1975; 30:489-96.

12 Fontana RS, Sanderson DR, Woolner LB et al. Mayo lung project for early detection and localization of bronchogenic carcinoma: a status report. Chest
1975: 67:511-22.

13 Krákora P, Trefný J, Kubík A. Detection and dispensary care of groups of persons at increased risk of bronchogenic cancer disease in Czechoslovakia. Vop Onkel 1977; 13:64-9. 